\title{
Diversity and Characterization of the Bacterial Communities of Different Water Resources in Egypt Concerning Contamination Type
}

\author{
Rashed A. Zaghloul ${ }^{1}$, Ahmed A. Salem ${ }^{1}$, Hany M. Abdel-Rahman ${ }^{1}$, Amira F. Hegab ${ }^{2}$, Ayman Y. I. Ewida ${ }^{2 *}$ \\ ${ }^{1}$ Agricultural Microbiology Department - Faculty of Agriculture - Benha University - Egypt. \\ ${ }^{2}$ Department of Microbiology - National Water Research Center - Cairo Egypt \\ *Corresponding Author: ayman_ibrahim@nwrc.gov.eg, ORCID; 000 - 0001 - 6913-6748.
}

\begin{abstract}
The habitat of microorganisms is different from one to another, some are naturally found in water environment, others are introduced due to different sources of contamination. The present study aimed to characterize the bacterial community of diverse water resources in Egypt in relation to the contamination source pursued them. So, water samples were collected from seven different water resources; groundwater, Nile River water, agricultural drainage water (El-Hussieniya drain), sewage contaminated drain (Bahr El-Baqr drain), industrial wastes contaminated drain (Al-Khadrawiya drain), fresh water Lake (Nasser Lake) and brackish water Lake (Qaroun Lake).

A total of 2218 bacterial isolates were collected, purified and identified by means of biochemical reactions and 16S rDNA sequence analysis to 21 bacterial genera. The sewage contaminated drain water (Bahr El-Baqr drain) has the highest diverse bacterial community, while the fresh water (Nasser) Lake has the lowest diverse community due to lake of contamination. In addition, Bacillus, Pseudomonas and Staphyllococcus were the most popular genera, where they have been detected in all types of water resources. The less popular genera were Yersinia, Klebsiella, Aerumonas, Shigella, Salmonella, Cardiobacterium, Arthrobacter and Streptobacillus, where they all have been detected once.
\end{abstract}

Key words: Diversity, Bacterial Communities, bacterial genera

\section{Introduction}

The term diversity describes heterogeneity within a system. As applied to ecology it refers to (i) the total number of species present in an ecosystem and (ii) the number of individuals of each species present in that ecosystem. When dealing with microbes individuals can only be identified using culture techniques. The selectivity of culturing microorganisms in the laboratory automatically introduces bias into measuring diversity. Even with the limitations imposed by the selectivity bias, it is evident that determining the number of individuals of each species present is not a practical undertaking (Barton and Northup, 2011)

Another widely used technique for estimating microbial diversity assumed by (Hirsch and RadesRohkohl, 1983; Stetzenbach et al., 1986 and Pedersen and Ekendahl, 1990) to recover microorganisms present in a given water resource, counting them and identifying them, using physiologic criteria. For example, Pedersen and Ekendahl (1990) recovered four species of bacteria from a depth of 463 meters in a granitic aquifer in Sweden. The total plate count of this sample was $3.9 \times 10^{4}$ cells $/ \mathrm{ml}$. Of this total, $3.2 \times 10^{4}$ cells were identified as Pseudomonas fluorescens. These data showed that most of the viable cells present at that sampling depth were from a single species. That is to say, the observed diversity was fairly low. In a similar study conducted by Stetzenbach et al. (1986) who identified bacteria isolated from groundwater produced from deep wells in Tucson, Arizona. They found that $70 \%$ of the total viable microorganisms present were members of the genus Acinetobacter. Almost $10 \%$ of the microorganisms present were an un-identified pigmented organism. It is evident that as in the example given by Pedersen and Ekendahl (1990) the diversity of the groundwater flora is fairly low.

The objective of the present study is to characterize the bacterial community of seven selected water resources and interpret the results with types and sources of contamination.

\section{Materials and Methods}

\subsection{Location of samples and description of sites} 2.1.1 Groundwater samples

Five shallow groundwater samples have been collected from hand pumps in some rural areas, locations and sites description are given in (Table 1). 
Table 1. Locations and sites descriptions of groundwater samples

\begin{tabular}{|c|c|c|c|}
\hline $\begin{array}{l}\text { Sample } \\
\text { No }\end{array}$ & Code & Location & Description \\
\hline 1 & G1 & $\begin{array}{l}\text { Aghour Assughra village - Qaluybia } \\
\text { Governorate }\end{array}$ & $\begin{array}{l}\text { Hand pump of depth } 30 \mathrm{~m} \text {, at a rural } \\
\text { house }\end{array}$ \\
\hline 2 & G2 & $\begin{array}{l}\text { Aghour Assughra village - Qaluybia } \\
\text { Governorate }\end{array}$ & $\begin{array}{l}\text { Old hand pump of depth } 35 \mathrm{~m} \text {, not in } \\
\text { use since a long time }\end{array}$ \\
\hline 3 & $\mathrm{D}$ & Darawa village - Munofia Governorate & $\begin{array}{l}\text { Hand pump of depth } 35 \mathrm{~m} \text {, at a rural } \\
\text { house }\end{array}$ \\
\hline 4 & MG & $\begin{array}{l}\text { Al Kharqaniyyah village - Qaluybia } \\
\text { Governorate }\end{array}$ & $\begin{array}{l}\text { Hand pump of depth } 60 \mathrm{~m} \text {, at a rural } \\
\text { house }\end{array}$ \\
\hline 5 & $\mathrm{Br}$ & Al Baradah village - Qaluybia Governorate & $\begin{array}{l}\text { Hand pump of depth } 20 \mathrm{~m} \text {, at a rural } \\
\text { house }\end{array}$ \\
\hline
\end{tabular}

\subsubsection{River Nile water samples}

Five water samples from River Nile have been collected from different sites, full description of sites and locations were given in (Table 2).

\subsubsection{Drains water samples}

Three drains were selected, one of them is receiving agricultural wastewater, the second is receiving domestic wastes, and the third is receiving industrial wastes. The full description of all the selected drains was illustrated in (Table 3).

Table 2. Locations and sites descriptions of Nile River water samples

\begin{tabular}{|c|c|c|c|}
\hline $\begin{array}{c}\text { Sample } \\
\text { No }\end{array}$ & Code & Location & Description \\
\hline 1 & AS & $\begin{array}{l}\text { River Nile at Aswan, after the high dam - } \\
\text { Aswan Governorate }\end{array}$ & $\begin{array}{l}\text { Beginning of River Nile upstream in } \\
\text { Egypt }\end{array}$ \\
\hline 2 & IM & $\begin{array}{l}\text { River Nile at Al-Wasta city - Beni Suef } \\
\text { Governorate }\end{array}$ & End of upper Egypt region \\
\hline 3 & $\mathrm{BH}$ & $\begin{array}{l}\text { River Nile at Bahadh village - Qaluybia } \\
\text { Governorate }\end{array}$ & Damietta branch \\
\hline 4 & NI & $\begin{array}{l}\text { River Nile at Al Qanatir Al Khayriyyah - } \\
\text { Qaluybia Governorate }\end{array}$ & Damietta branch \\
\hline 5 & Ds & $\begin{array}{l}\text { River Nile at Desouk - Kafr El Sheikh } \\
\text { Governorate }\end{array}$ & $\begin{array}{l}\text { Rosetta branch after the discharge of } \\
\text { El-Rahawy drain }\end{array}$ \\
\hline
\end{tabular}

Table 3. Locations and sites descriptions of drains water samples

\begin{tabular}{|c|c|c|c|}
\hline $\begin{array}{c}\text { Sample } \\
\text { No }\end{array}$ & Code & Location & Description \\
\hline 1 & $\mathrm{Hu}$ & $\begin{array}{l}\text { Sahl El-Husseiniya drain. } \\
\text { Samples collected from the } \\
\text { drain before connecting with } \\
\text { Bahr El-baqar drain }\end{array}$ & $\begin{array}{l}\text { Receives agricultural wastewater from Sahl El- } \\
\text { Husseiniya city, Alsharqia Governorate }\end{array}$ \\
\hline 2 & $\mathrm{BR}$ & $\begin{array}{l}\text { Bahr El-Baqar drain. Samples } \\
\text { were collected from the drain at } \\
\text { Port Saied Governorate, before } \\
\text { connecting with Manzala lake }\end{array}$ & $\begin{array}{l}\text { It is considered as one of the most polluted drains in } \\
\text { Egypt (Abdel-Shafy and Aly, 2002). Discharge about } \\
2.3 \mathrm{BCM} \text { /year to Manzala lake. It is passing through } \\
\text { four highly populated Governorate; Qalubeya, Sharkia, } \\
\text { Ismailia and Port Said. Receives agricultural, domestic } \\
\text { and industrial wastewaters. }\end{array}$ \\
\hline 3 & $\mathrm{Kh}$ & $\begin{array}{l}\text { Al-Khadrawiya drain. } \\
\text { Samples collected from Quesna } \\
\text { industrial region, Munofia } \\
\text { Governorate }\end{array}$ & $\begin{array}{l}\text { Receives mainly industrial wastewater from factories } \\
\text { pipes extended from Quesna industrial zone, Munofia } \\
\text { Governorate }\end{array}$ \\
\hline
\end{tabular}

\subsubsection{Lakes water samples}

Two Lakes were selected; Nasser Lake (as an example of fresh water Lake), and Qaroun Lake (as an example of brackish water Lake), as shown in (Table 4). 
Table 4. Locations and sites descriptions of Lakes water samples

\begin{tabular}{|c|c|c|c|}
\hline $\begin{array}{c}\text { Sample } \\
\text { No }\end{array}$ & Code & Location & Description \\
\hline 1 & NL & $\begin{array}{l}\text { Nasser Lake, } \\
\text { Aswan } \\
\text { Governorate }\end{array}$ & $\begin{array}{l}\text { It was generated by the construction of the Aswan High Dam } \\
\text { between January } 1964 \text { and June } 1968 \text { (Salih et al. 2019). The area of } \\
\text { the Lake is about } 5000 \mathrm{~km}^{2} \text {. The mean depth is } 90 \mathrm{~m} \text { and the } \\
\text { maximum width is about } 60 \mathrm{~km} \text { (Farhat and Aly 2018). }\end{array}$ \\
\hline 2 & QL & $\begin{array}{l}\text { Qaroun lake, Al- } \\
\text { Fayoum } \\
\text { Governorate }\end{array}$ & $\begin{array}{l}\text { Brackish water lake, receives discharges contaminated with } \\
\text { agricultural, industrial and sewage wastes from El-Bats and El-Wadi } \\
\text { drains without prior treatments (Derbala, 2018). }\end{array}$ \\
\hline
\end{tabular}

\subsection{Diversity and characterization of the bacterial community of each water resource}

\subsubsection{Isolation, purification and pre-identification of bacterial isolates}

Total viable bacterial count has been performed for each water resource. The growing colonies of each plate were differentiated and categorized according to the cultural characteristics, and then they were purified and maintained for further identification. The purified isolates were subjected to preidentification, which included culture characteristics, Gram stain, biochemical characterization according to Bergey's manual of systematic bacteriology (Krieg and Holt, 1986; Sneath et al. 1986) They were classified to groups according to their Gram reactions; Gram positive cocci, Gram negative rods and Gram positive rods.

2.2.2 Full identification of the bacterial community of each water resource

The pre-identified isolates have been subjected to $16 \mathrm{~S}$ rDNA sequencing for confirming their identification. DNA was extracted using the GeneJet genomic DNA extraction kit (Thermo K0721). PCR amplification of the 16S rDNA gene was performed using $10 \mathrm{ng}$ of genomic DNA in $20 \mu \mathrm{l}$ of $1 \times$ Amplitaq (Perkin-Elmer, 940 Winter Street, Waltham, Massachusetts 02451 , USA) buffer $(10 \mathrm{mmol} / \mathrm{l}$ Tris $\mathrm{HCl}, 50 \mathrm{mmol} / \mathrm{l} \mathrm{KCl}, 1.5 \mathrm{mmol} / \mathrm{l} \mathrm{MgCl} 2,0.001 \%$ gelatin) with $150 \mathrm{ng}$ each of primers, F: 5 AGA GT T TG A TC C TGG CTC AG-3' and R: 5 GGT T AC C TT GTT ACG ACT T-3', $250 \mu \mathrm{mol} / 1$ of dNTPs, and IU of Amplitaq (Perkin-Elmer). Reaction mixtures of PCR were incubated at $95^{\circ} \mathrm{C}$ for $3 \mathrm{~min}$, then cycled 35 times as follows: annealing for $30 \mathrm{sec}$ at $95^{\circ} \mathrm{C}$, and at $72^{\circ} \mathrm{C}$ for $4 \mathrm{~min}$. Annealing temperature was $60^{\circ} \mathrm{C}$ for the first five cycles, $55^{\circ} \mathrm{C}$ for the next five cycles, and $50^{\circ} \mathrm{C}$ for the last 25 cycles. Finally, the mixtures were incubated at $72^{\circ} \mathrm{C}$ for $10 \mathrm{~min}$ and at $60^{\circ} \mathrm{C}$ for $10 \mathrm{~min} ; 2.0 \mu \mathrm{l}$ of each amplification mixture was analyzed by agarose gel $(1.0 \% \mathrm{w} / \mathrm{v})$ electrophoresis in a TAE buffer $(0.04$ mol/1 Tris-acetate, 0.001 MEDTA) containing 0.5 $\mathrm{mg} / \mathrm{ml} \mathrm{(w/v)} \mathrm{ethidium} \mathrm{bromide.} \mathrm{Sequencing} \mathrm{was}$ carried out at Biomolecular Research Services (GATC Biotech, Konstanz, Germany) using ABI $37301 \times$ DNA sequencer with the same forward and reverse primers. The sequences obtained in this study were aligned to the GenBank database with the maximum similarity and identity using MEGA 6 database.

\subsection{Statistical analysis of data}

The predominated genera in each community, the most and the seldom present genera, the percentage of each group of bacteria and the percentage of each species were determined using STATISTICA software, ver 4.

\section{Results and Discussion}

\subsection{Diversity and characterization of the bacterial community in Groundwater}

The identified isolates in groundwater are characterized as Gram-positive rods (35.8\%), Grampositive cocci $(29.6 \%)$ and Gram-negative rods $(34.6 \%)$ as illustrated in table (5) and fig (1). In addition, Staphylococcus aureus and Bacillus polymyxa recorded the highest number of isolates in the bacterial community, while Pectobacterium and Streptobacillus moniliformis recorded the lowest number. As the groundwater tested in the present work was free from sewage or industrial contamination (Chapelle, 2001), the bacterial community is considered of moderate diversity. 
Table 5. Characterization of the bacterial community in groundwater

\begin{tabular}{ccccc}
\hline Bacterial group & $\begin{array}{c}\text { Identified bacterial } \\
\text { community in groundwater }\end{array}$ & No. of isolates & $\begin{array}{c}\text { Isolate (\%) in } \\
\text { the community }\end{array}$ & $\begin{array}{c}\text { Group (\%) in } \\
\text { the community }\end{array}$ \\
\hline \multirow{2}{*}{ Gram positive cocci } & Staphylococcus aureus & 12 & 14.8 & 29.6 \\
& Micrococcus & 3 & 3.7 & 11.1 \\
Streptococcus faecalis & 9 & 9.8 \\
Gram negative rods & Flavobacterium & 8 & 12.3 \\
& Pseudomonas & 10 & 2.4 \\
Pectobacterium & E. coli & 8 & 9.8 \\
Gram positive & Bacillus polymyxa & 12 & 14.8 \\
& Bacillus licheniformis & 3 & 3.7 \\
& Bacillus subtilis & 5 & 6.1 \\
& Bacillus cereus & 7 & 8.6 \\
\hline
\end{tabular}

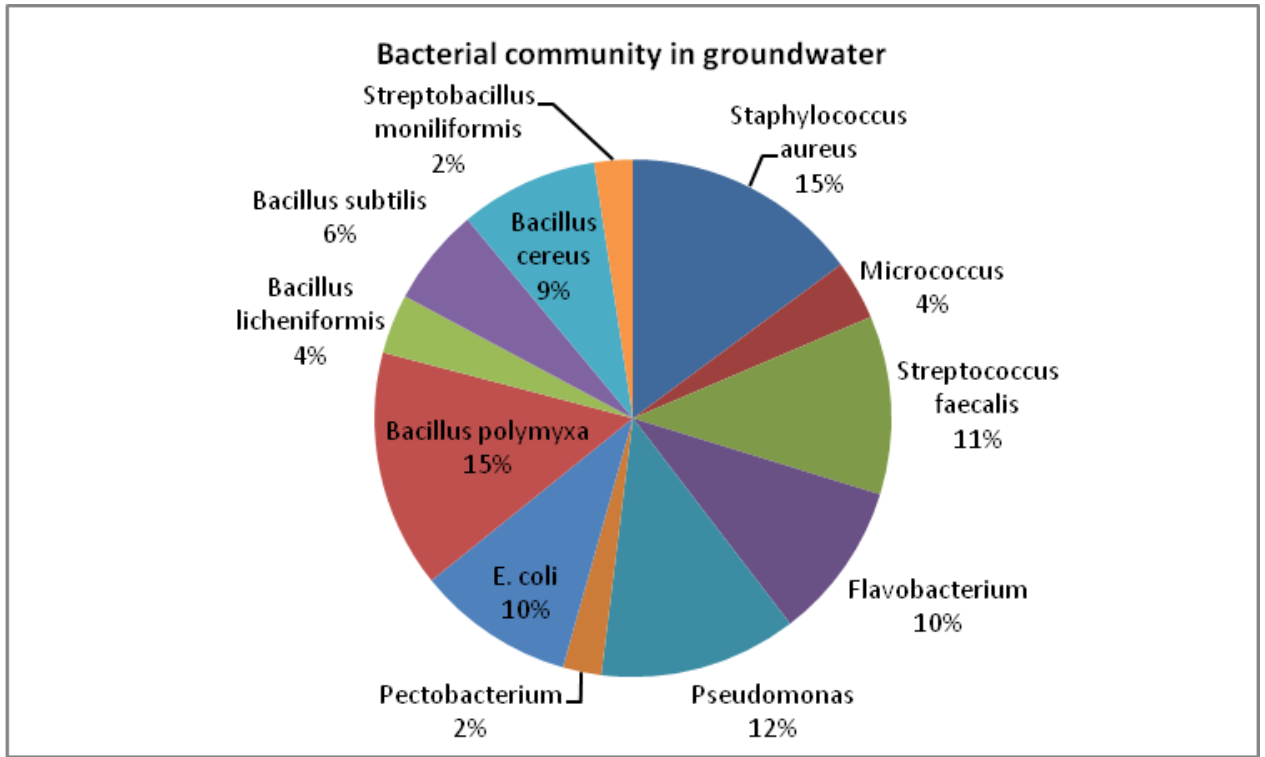

Fig (1): Characterization of the bacterial community in groundwater

\subsection{Diversity and characterization of bacterial community in Nile River water}

The identified isolates in Nile River water are characterized as Gram-negative rods $(39.6 \%)$ Grampositive rods $(36.9 \%)$ and Gram positive cocci $(22.9 \%)$ as illustrated in table (6) and fig (2). It was noticed that genus Bacillus (constitutes $32.5 \%$ of the community) and Pseudomonads (constitute $14.3 \%$ of the community) approximately comprise the half of the bacterial community of Nile River water, as they are normal inhabitants of soil and water, so, the contamination of such water is of acceptable ranges, and the diversity of bacterial community in such water resource is considered moderate.

\subsection{Diversity and characterization of bacterial community in agricultural drainage water}

The Agricultural drain water was characterized by a high number of Gram negative rods $(67.5 \%)$ of the community, while the Gram positive cocci $(18 \%)$ and the Gram positive rods (14.3\%), as indicated in table (7) and fig (3). The majority of the community is included in Gram negative bacteria, nevertheless, there were only 6 genera have been identified. In addition, there are 2 genera of Gram positive cocci and 1 genus in Gram positive rods have been identified. So, the bacterial community in the tested agriculture drain water is considered of moderate diversity. 
Table 6. Characterization of the bacterial community in Nile River water

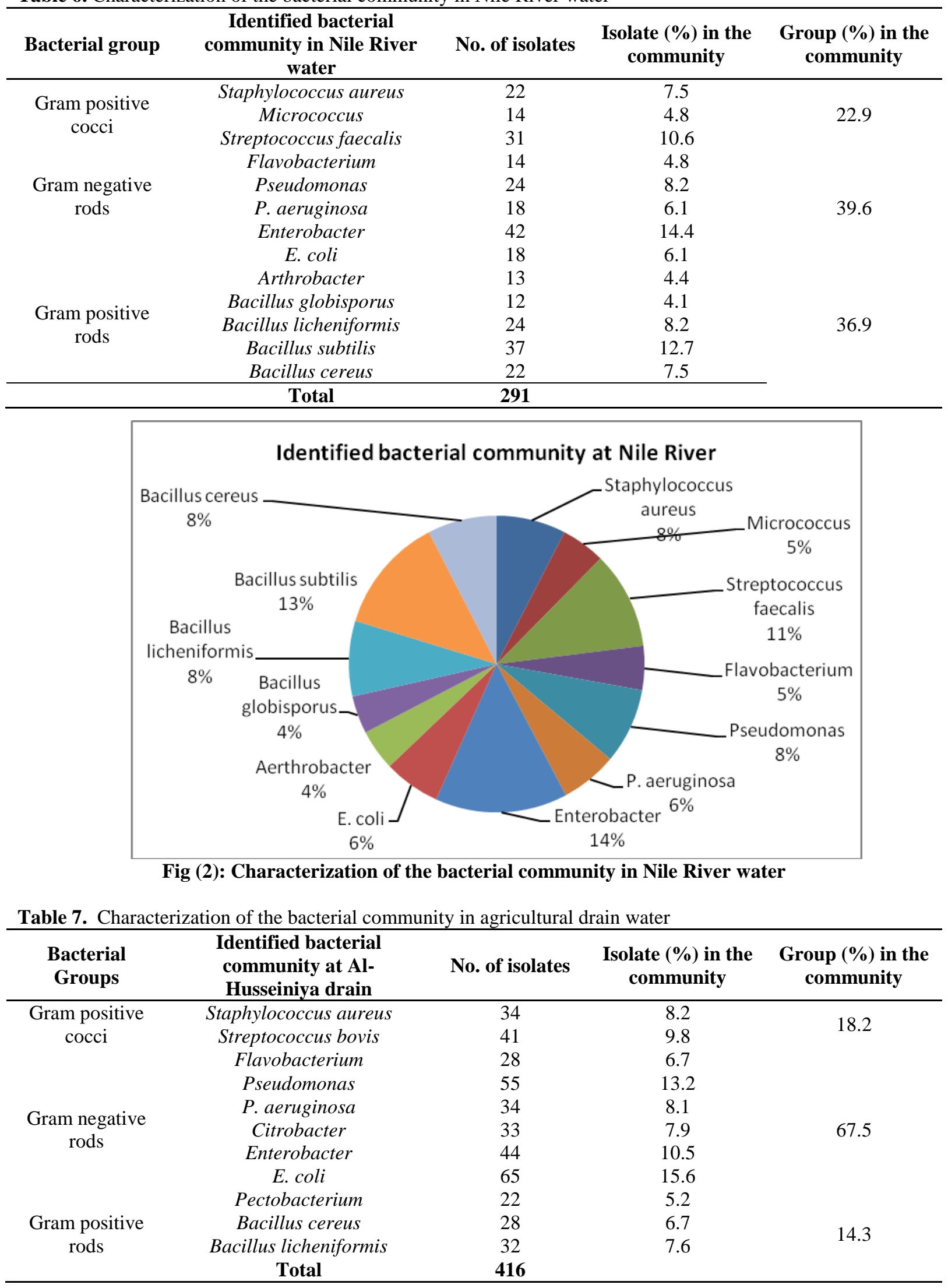




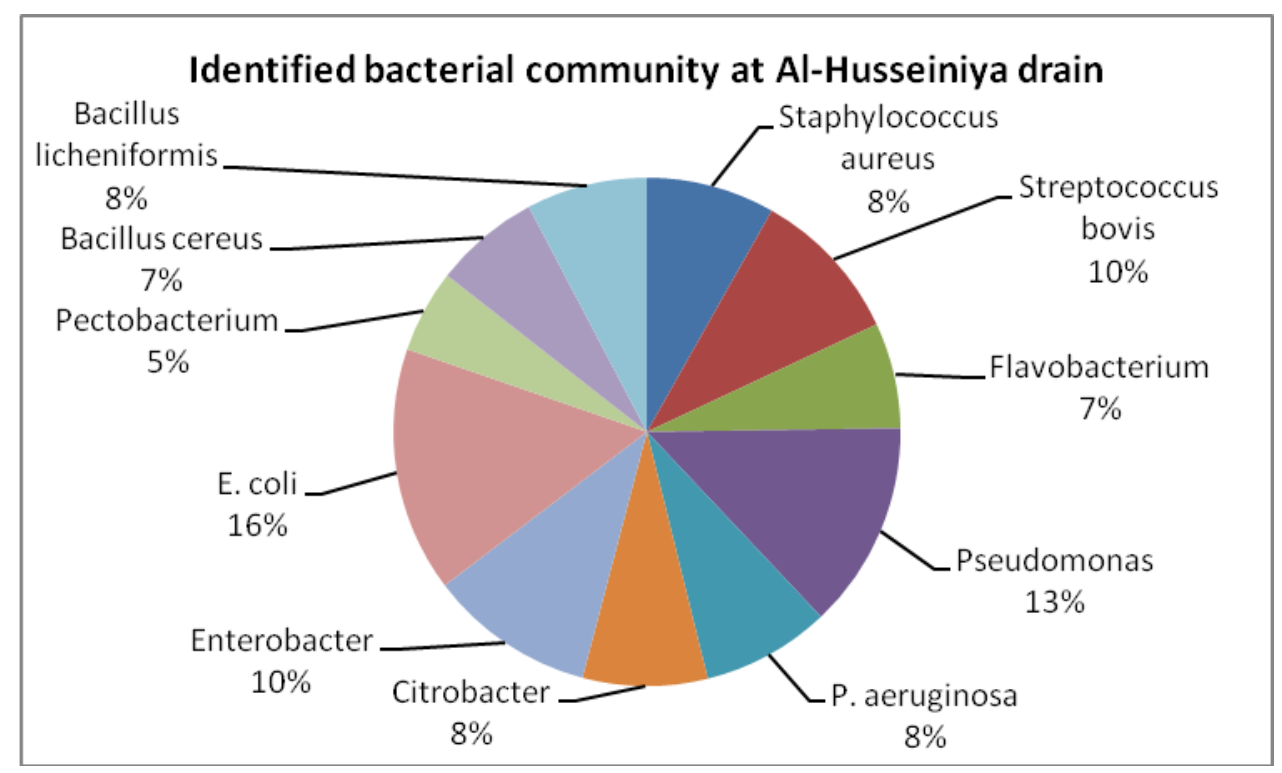

Fig (3): Characterization of the bacterial community in agricultural drainage water

3.4 Diversity of bacterial community in sewage contaminated drains

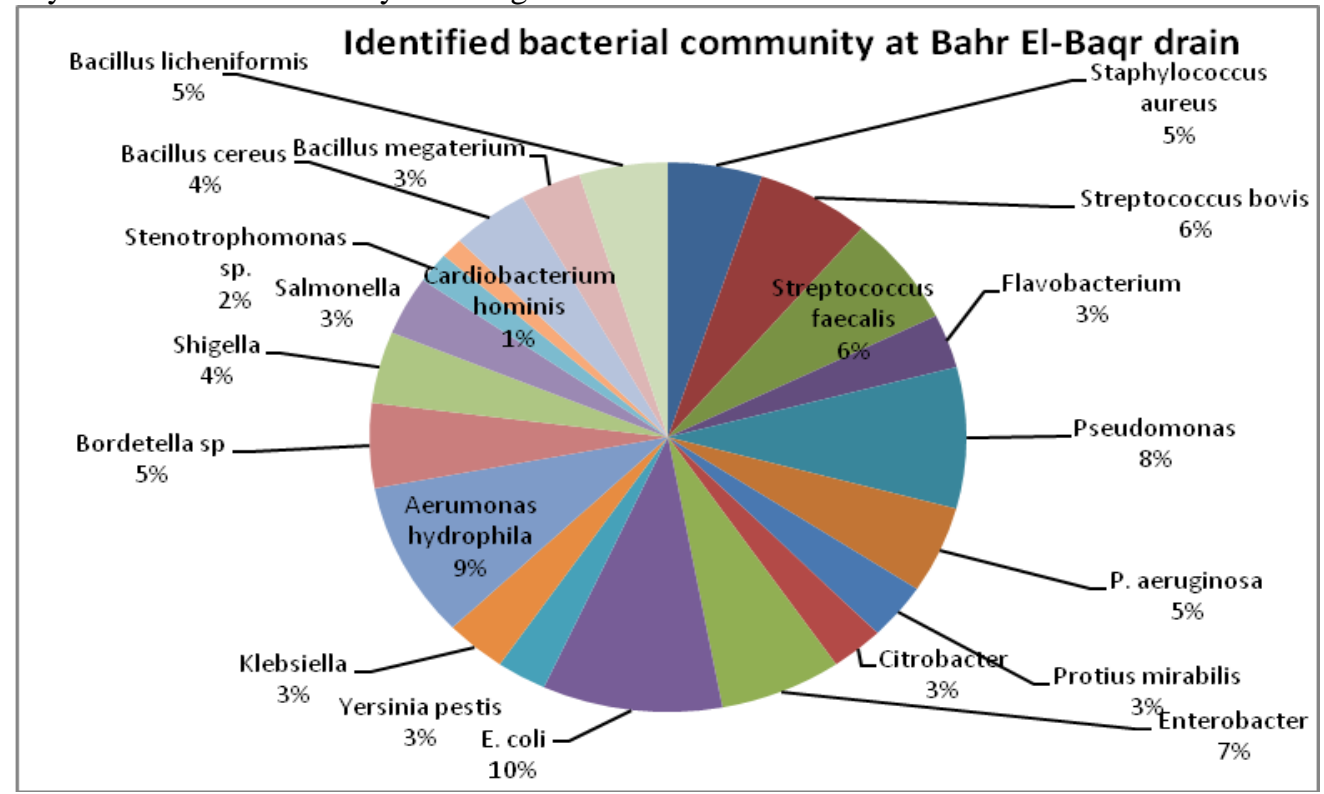

Fig (3): Characterization of the bacterial community in sewage drainage water

The majority of the bacterial isolates in sewage contaminated drainage water (Bahr El-baqr drain) were belonged to Gram negative rods, where they constitute $67.9 \%$ of the bacterial community. The identified bacterial community is given in table (8) and figure (5) where it contains 14 genera of Gram negative bacteria most of them belong to enterobacteriacea family due to sewage contamination. In addition, there are some genera have been rarely isolated like Stenotrophomonas and Cardiobacterium. The presence of Shigella is indicative for the renewable source of contamination of sewage. In conclusion, the bacterial community of Bahr El-Baqr drainage water as an example of sewage contaminated water is considered of high diversity. 
Table 8. Characterization of the bacterial community in sewage contaminated drain

\begin{tabular}{|c|c|c|c|c|}
\hline Bacterial Groups & $\begin{array}{c}\text { Identified bacterial } \\
\text { community at Bahr El-Baqr } \\
\text { drains }\end{array}$ & $\begin{array}{c}\text { No. of } \\
\text { isolates }\end{array}$ & $\begin{array}{l}\text { Isolate }(\%) \text { in } \\
\text { the community }\end{array}$ & $\begin{array}{l}\text { Group }(\%) \text { in } \\
\text { the community }\end{array}$ \\
\hline \multirow{4}{*}{ Gram positive cocci } & Staphylococcus aureus & 34 & 5.0 & \multirow{4}{*}{17.2} \\
\hline & Streptococcus bovis & 41 & 6.0 & \\
\hline & Streptococcus faecalis & 43 & 6.3 & \\
\hline & Flavobacterium & 21 & 3.1 & \\
\hline \multirow{12}{*}{ Gram negative rods } & Pseudomonas & 55 & 8.0 & \multirow{12}{*}{67.9} \\
\hline & P. aeruginosa & 34 & 5.0 & \\
\hline & Protius mirabilis & 22 & 3.2 & \\
\hline & Citrobacter & 19 & 2.8 & \\
\hline & Enterobacter & 44 & 6.4 & \\
\hline & E. coli & 65 & 9.5 & \\
\hline & Yersinia pestis & 18 & 2.6 & \\
\hline & Klebsiella & 22 & 3.2 & \\
\hline & Aerumonas hydrophila & 61 & 8.9 & \\
\hline & Bordetella sp & 33 & 4.8 & \\
\hline & Shigella & 28 & 4.1 & \\
\hline & Salmonella & 23 & 3.4 & \\
\hline \multirow{7}{*}{ Gram positive rods } & Stenotrophomonas sp. & 12 & 1.8 & \multirow{7}{*}{14.9} \\
\hline & Cardiobacterium hominis & 8 & 1.2 & \\
\hline & Bacillus cereus & 28 & 4.1 & \\
\hline & Bacillus megaterium & 22 & 3.2 & \\
\hline & Bacillus licheniformis & 32 & 4.7 & \\
\hline & Bacillus subtilis & 20 & 2.9 & \\
\hline & Total & 685 & & \\
\hline
\end{tabular}

\subsection{Diversity and characterization of bacterial community in industrial wastes contaminated drainage water}

The bacterial community of the industrially contaminated drain water (Al-Khadrawiya drain) was characterized by a high number of Gram negative rods $(68.4 \%)$ as indicated in table (9) and fig (5). The bulk of the community is included in two genera; Pseudomonas (25.7\%) and Bacillus (21.8\%), these two prompt genera have been reported in the literature as strong bio-removers for chemical contamination of water so, they could predominate the community (Ewida, 2014; Jahin et al, 2014; Chuahan et al, 2016; Pathak et al, 2016; Ewida, 2020; Ewida et al, 2021). The total number of identified genera in the community was 9 , so, it is considered of moderate diversity. 
Table 9. Characterization of the bacterial community in industrial wastes contaminated drain

\begin{tabular}{|c|c|c|c|c|}
\hline Bacterial Groups & $\begin{array}{l}\text { Identified bacterial } \\
\text { community at Al- } \\
\text { Khadrawiya drain }\end{array}$ & $\begin{array}{c}\text { No. of } \\
\text { isolates }\end{array}$ & $\begin{array}{l}\text { Isolate }(\%) \text { in } \\
\text { the community }\end{array}$ & $\begin{array}{l}\text { Group }(\%) \text { in } \\
\text { the community }\end{array}$ \\
\hline \multirow[t]{4}{*}{ Gram positive cocci } & Streptococcus faecalis & 33 & 9.6 & \multirow[t]{4}{*}{9.6} \\
\hline & Pseudomonas & 33 & 9.6 & \\
\hline & P. aeruginosa & 55 & 16.1 & \\
\hline & Protius mirabilis & 35 & 10.2 & \\
\hline \multirow{5}{*}{ Gram negative rods } & Citrobacter & 22 & 6.4 & \multirow{4}{*}{68.2} \\
\hline & Enterobacter & 32 & 9.3 & \\
\hline & E. coli & 26 & 7.6 & \\
\hline & Bordetella sp & 19 & 5.5 & \\
\hline & Stenotrophomonas sp. & 12 & 3.5 & \multirow{4}{*}{21.8} \\
\hline \multirow{3}{*}{ Gram positive rods } & Bacillus cereus & 31 & 9 & \\
\hline & Bacillus megaterium & 44 & 12.8 & \\
\hline & Total & 342 & & \\
\hline
\end{tabular}

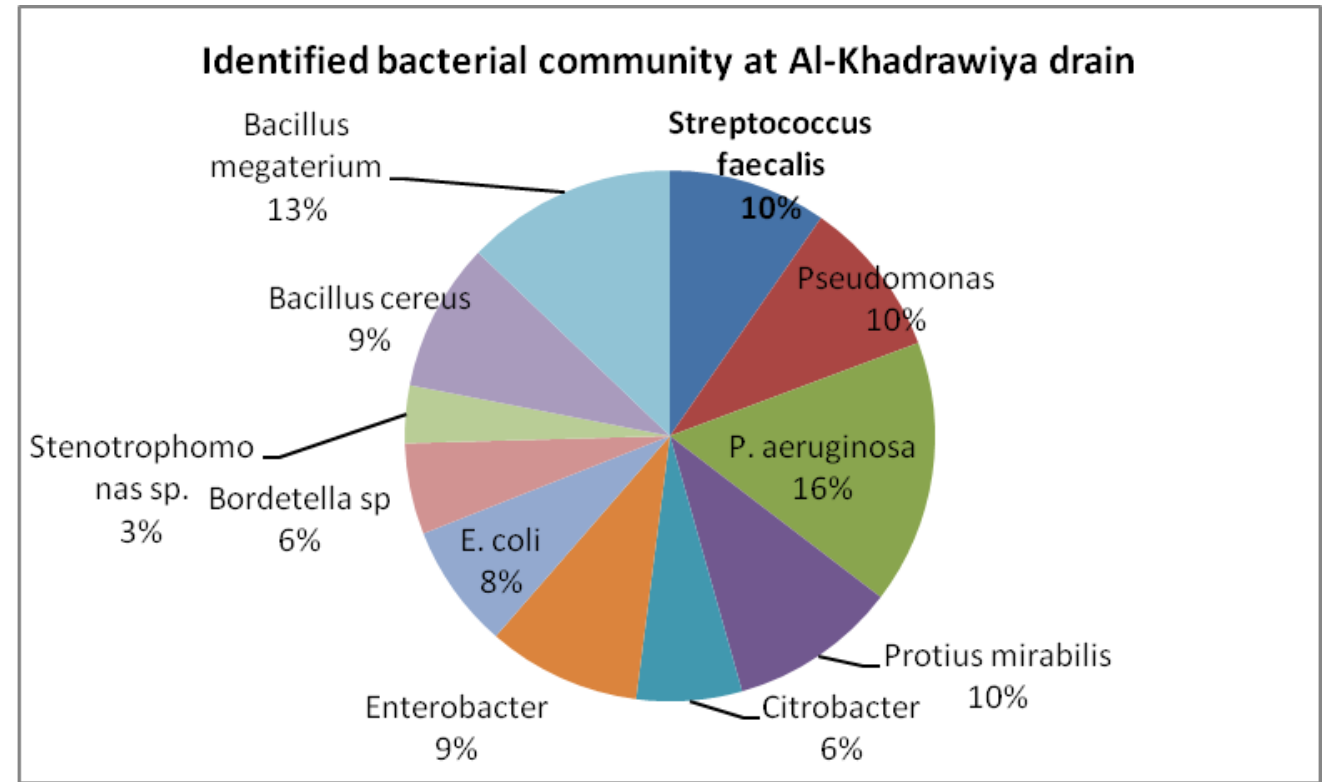

Fig (5): Characterization of the bacterial community in industrial wastes contaminated drain water

3.6 Diversity and characterization of bacterial community in fresh water Lake

Small number of isolates has been collected from Nasser Lake water, which confirms that the bacterial community at this Lake is considered of low diversity. Nevertheless, the three bacterial groups were detected; Gram positive cocci represented genus Staphylococcus aureus and Streptococcus bovis which constituted $34.8 \%$ of the total number of isolates, the Gram-negative rods constituted $40.4 \%$ of total number of isolates. The percentage of Grampositive rods was $24.7 \%$ including only one species (Bacillus cereus). 
Table 10. Characterization of the bacterial community in fresh water Lake (Nasser Lake)

\begin{tabular}{|c|c|c|c|c|}
\hline Bacterial Groups & $\begin{array}{c}\text { Identified } \\
\text { bacterial } \\
\text { community at } \\
\text { Nasser Lake }\end{array}$ & $\begin{array}{c}\text { No. of } \\
\text { isolate } \\
\quad s\end{array}$ & $\begin{array}{l}\text { Isolate }(\%) \text { in the } \\
\text { community }\end{array}$ & $\begin{array}{l}\text { Group }(\%) \text { in the } \\
\text { community }\end{array}$ \\
\hline \multirow{2}{*}{$\begin{array}{l}\text { Gram positive } \\
\text { cocci }\end{array}$} & $\begin{array}{c}\text { Staphylococcu } \\
\text { s aureus }\end{array}$ & 17 & 19.1 & \multirow{2}{*}{34.8} \\
\hline & $\begin{array}{c}\text { Streptococcus } \\
\text { bovis }\end{array}$ & 14 & 15.7 & \\
\hline \multirow{2}{*}{$\begin{array}{l}\text { Gram negative } \\
\text { rods }\end{array}$} & Pseudomonas & 16 & 17.98 & \multirow{2}{*}{40.4} \\
\hline & Enterobacter & 20 & 22.47 & \\
\hline \multirow[t]{2}{*}{ Gram positive rods } & $\begin{array}{c}\text { Bacillus } \\
\text { cereus }\end{array}$ & 22 & 24.7 & 24.7 \\
\hline & Total & 89 & & \\
\hline
\end{tabular}

\section{Identified bacterial community at Nasser Lake}

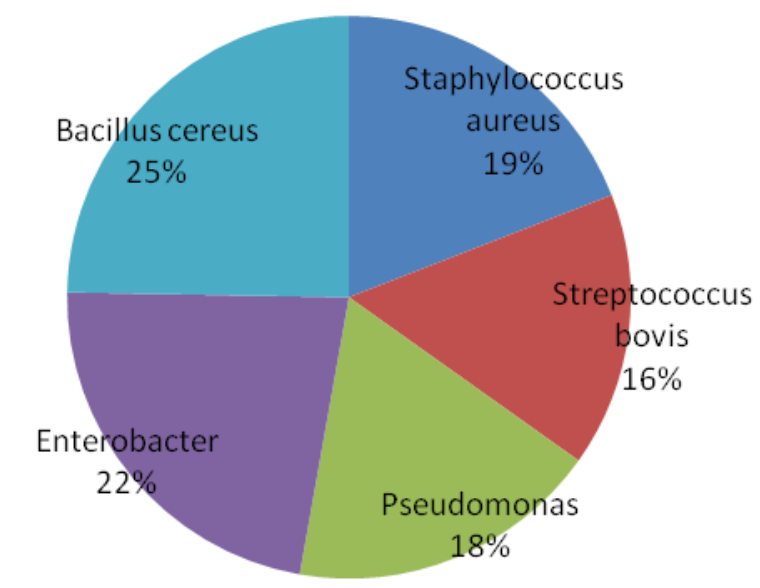

Fig (6): Characterization of the bacterial community in Nasser Lake water

\subsection{Diversity and characterization of bacterial community in brackish water Lake}

The identified isolates in brackish water Lake are characterized as Gram-negative rods (45.2\%), Grampositive cocci $(30.2 \%)$ and Gram-positive rods $(24.5 \%)$ as illustrated in table (11) and fig (7). The presence of streptococci in high content of the identified isolates (about one-fifth of the community) might be attributed to the presence of thousands of migratory birds which always rest at Qaroun Lake during their winter migration (Derbala, 2018). In general, the bacterial community at Qaroun Lake is considered of moderate diversity. It is clear that the Gram negative bacteria were found to constitute the highest percentages of the bacterial communities in each studied water resource, these results are in agreement with those obtained by Balkwill and Ghiorse (1985) who studied the bacterial community at a shallow water table aquifer in Oklahoma; they reported that about two-thirds of the isolated bacteria were Gram negative. In a carbonate aquifer in the Atlantic coastal plain (Chapelle et al., 1988), about $70 \%$ of the isolates recovered were Gram negative. Heikal (2000) studied the bacteriological quality of the groundwater at El-Qanater village, Kalubiya governorate, a total of 500 isolates were collected from 26 groundwater wells. He reported that aerobic Gram negative rods were constitute $46 \%$, while the facultative anaerobic Gram negative rods constituting $16 \%$, and Gram positive cocci, as well as, Gram positive rods constituting $26 \%$ and $8 \%$, respectively. 
Table 11. Characterization of the bacterial community in brackish water Lake (Qaroun Lake)

\begin{tabular}{|c|c|c|c|c|}
\hline Bacterial Groups & $\begin{array}{c}\text { Identified } \\
\text { bacterial } \\
\text { community at } \\
\text { Qaroun Lake }\end{array}$ & $\begin{array}{l}\text { No. of } \\
\text { isolate } \\
\quad \mathrm{s}\end{array}$ & $\begin{array}{l}\text { Isolate }(\%) \text { in the } \\
\text { community }\end{array}$ & $\begin{array}{l}\text { Group }(\%) \text { in the } \\
\text { community }\end{array}$ \\
\hline \multirow{3}{*}{$\begin{array}{l}\text { Gram positive } \\
\text { cocci }\end{array}$} & $\begin{array}{c}\text { Staphylococcu } \\
\text { s aureus }\end{array}$ & 32 & 10.2 & \multirow{4}{*}{30.2} \\
\hline & $\begin{array}{c}\text { Streptococcus } \\
\text { bovis }\end{array}$ & 29 & 9.2 & \\
\hline & $\begin{array}{l}\text { Streptococcus } \\
\text { faecalis }\end{array}$ & 34 & 10.8 & \\
\hline \multirow{5}{*}{$\begin{array}{l}\text { Gram negative } \\
\text { rods }\end{array}$} & P. aeruginosa & 38 & 12.1 & \\
\hline & Protius & 28 & 9 & \multirow{4}{*}{45.2} \\
\hline & Citrobacter & 22 & 7 & \\
\hline & Enterobacter & 12 & 3.8 & \\
\hline & E. coli & 19 & 6 & \\
\hline \multirow{5}{*}{ Gram positive rods } & Bordetella sp & 23 & 7.3 & \multirow{5}{*}{24.5} \\
\hline & $\begin{array}{c}\text { Bacillus } \\
\text { cereus }\end{array}$ & 32 & 10.2 & \\
\hline & $\begin{array}{c}\text { Bacillus } \\
\text { licheniformis }\end{array}$ & 21 & 6.6 & \\
\hline & $\begin{array}{l}\text { Bacillus } \\
\text { subtilis }\end{array}$ & 24 & 7.6 & \\
\hline & Total & 314 & & \\
\hline
\end{tabular}

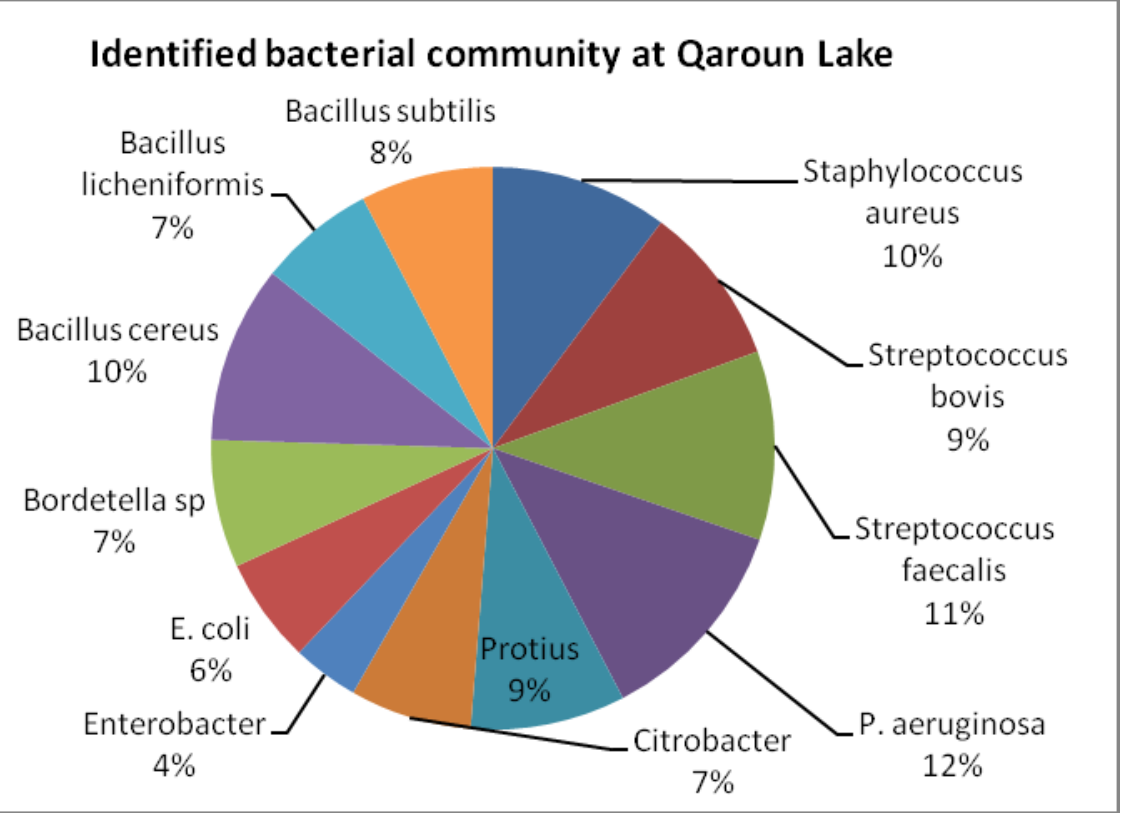

Fig (7): Characterization of the bacterial community in Qaroun Lake water

\section{Conclusion}

Seven different water resources were selected to carry out the study; groundwater, Nile River water, agricultural drain water (El-Hussieniya drain), sewage contaminated drain (Bahr El-Baqr drain), industrial wastes contaminated drain (Al-Khadrawiya drain), fresh water Lake (Nasser Lake) and brackish water Lake (Qaroun Lake). A total of 2218 bacterial isolates were collected, purified and identified to 21 bacterial genera. The most popular genera were Bacillus, Pseudomonas and Staphyllococcus, where they present in all types of water resources. The less popular genera were Yersinia, Klebsiella, Aerumonas, Shigella, Salmonella, Cardiobacterium, Arthrobacter and Streptobacillus, where they all are present once. Furthermore, the sewage contaminated 
drain water has the highest diverse community, while the fresh water (Nasser) Lake has the lowest diverse community.

\section{References}

Abdel-Shafy, HI and Aly, RO (2002). Water issue in Egypt: Resources, pollution and protection endeavors. Central European Journal of Medicine, 8(1)3 - 21.

Balkwill, D. L. and Ghiorse, W. C. (1985). Characterization of subsurface bacteria associated with two shallow aquifers in Oklahoma. J. Appl. Environ. Microbiol. 50: 580 -588 .

Barton, LL, Northup, DE (2011). Diversity of Microorganisms. In "Microbial Ecology". 1st ed. 2011 Wiley-Blackwell. John Wiley \& Sons, Inc.

Chapelle, F. H. (2001). History, Geology and Microbiology. and Microbial Ecology of Groundwater Systems. In: "Groundwater Microbiology and Geochemistry". ( $2^{\text {nd }}$ ed.), P: 3 - 31 and $150-187$. John Wiley and Sons, U.S.A.

Chapelle, F. H., Morris, J. T., McMahon, P. B. and Zelibor, J. L. (1988). Bacterial metabolism and the del-13C composition of groundwater, Floridan aquifer, South Carlolina. J. Geology 16: $117-121$.

Chauhan, A., Pathak, A., Ewida, A.Y.I., Griffiths, Z., and Stothard, P. (2016). Whole genome sequence analysis of an Alachlor and Endosulfan degrading Pseudomonas strain W15Feb9B isolated from Ochlockonee River, Florida. Genomics Data J. 8: 134 - 138.

Derbala, R.S.M. (2018) Environmental impact assessment of main drains on water and fish quality of Lake Qaroun at Fayoum Governorate. M.Sc Faculty of Science Fayoum University.

Ewida, AYI (2014). Biodegradation of alachlor and endosulfan using environmental bacterial strains. World Applied Sciences J. 32(4): $540-$ 547.

Ewida, AYI (2020). Bio-treatment of maize processing wastewater using indigenous microorganisms. Sustain Environ Res 30, 3. https://doi.org/10.1186/s42834-020-0044-1.

Ewida, AYI, Hegab, AF, Zaghloul, RA, Salem, AA, Abdel-Rahman, HM (2021). Environmental impact assessment of different water resources in Egypt in comparison with antibiotic resistance activity of their bacterial communities. Am Sci 17(4):26-36.

Farhat, H.I. and Aly, W. (2018) Effect of site on sedimentological characteristics and metal pollution in two semi-enclosed embayments of great freshwater reservoir: Lake Nasser, Egypt. J Afr Earth Sci 141: 194-206

Heikal M. T. (2000). Environmental studies on antibiotic resistant bacteria in some locations along the river Nile. Ph.D. Thesis: Institute of Environmental Studies and Researches. Ain Shams Univ., Egypt.

Hirsch, P. and Rades-Rohkohl. E. (1983). Microbial diversity in a groundwater aquifer in northern Germany. Develop. J. Indust. Microbiol. 24: $183-200$.

Jahin, HS, Gaber, SE and Ewida, AYI (2014). Biodegradation of phenantherene by native bacterial strains isolated from the river Nile water in Egypt. Nature and Science J. 12(1):18 .

Krieg, N.R. and Holt, J.G. (1986) Bergey's Manual of Systematic Bacteriology. (Vol. 1). Williams and Wilkins, Baltimore, U.S.A

Pathak, A., Chauhan, A., Ewida A.Y.T. and Stothard, P. (2016). Whole genome sequence analysis of an Alachlor and Endosulfan degrading Micrococcus sp. strain 2385 isolated from Ochlockonee River, Florida. J. Genomics 4: $42-$ 47.

Pedersen, K. and Ekendahl, S. (1990). Distribution and activity of bacteria in deep granitic ground waters of southeastern Sweden. J. Microbial Ecol. 20: 37-52.

Salih, S.Q., Allawi, M.F., Yousif, A.A., Armanuos, A.M., Saggi, M.K., Ali, M., and Chau, K.W. (2019) Viability of the advanced adaptive neuro-fuzzy inference system model on reservoir evaporation process simulation: case study of Nasser Lake in Egypt. Eng Appl Comput Fluid Mech 13(1):878-891

Sneath, P. H., Mair, N. S., Sharpe, E. and Holt J. G. (1986). Bergey's Manual of Systematic Bacteriology. (Vol. 2). Williams and Wilikins, Baltimore, U.S.A

Stetzenbach, L. D., Delley, L. M. and Sinclair, N. A. (1986). Isolation and growth of well water bacteria. J. Ground Water 24: 6-10. 


\section{الملخص العربى}

يختلف مواطن الكائنات الحيه الدقيقه من مكان لاخر، وبعضها موجود بشكل طبيعى فى البيئه المائيه، ويتم ادخال البعض الاخر بسبب مصادر

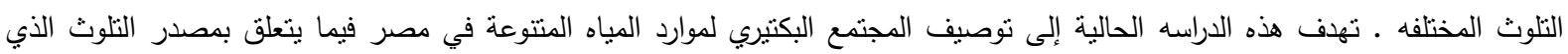

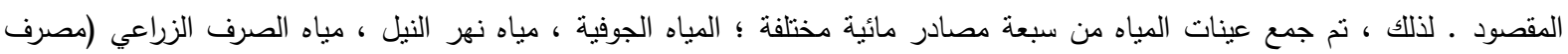
الحسينية) ، الصرف الصحي الملوث (مصرف بحر البقر) ، الصرف الملوث بالنفايات الصناعبة (مصرف الخضراوية) ، بحيرة المباه العذبة (بحيرة ناصر) وبحيرة المياه معتدلة الملوحة ( بحيرة قارون).تم جمع عدد 2218 عزله بكتيريه بكتيرية وتتقيتها وتحديدها عن طريق التفاعلات الكيميائية الحيوية وتحليل تسلسلى وتمت التصفيه الى 21عزله (جنس بكتيرى) تحتوي مياه الصرف الملوثة بمياه الصرف الصحي (مصرف بحر البقر) على اعلى مجتمع بكتيرى

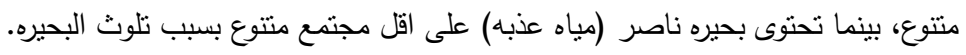

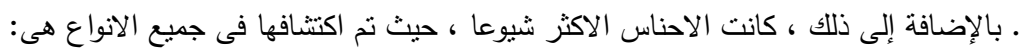

Bacillus, Pseudomonas and Staphyllococcus

$$
\text { وكانت الاجناس الاقل شيوعا هى : }
$$

Streptobacillus, Arthrobacter, Cardiobacterium, Salmonella و Shigella و Aerumonas , Klebsiella ,Yersinia حيث تم اكتشافهم جميعا. 